\title{
A STUDY ON THE GROWING PROCLIVITY TOWARDS GREEN MARKETING: ITS OPPORTUNITIES AND IMPLICATIONS
}

\section{KEY WORDS: Green}

Marketing, environment safety, awareness, impact of pollutants.

\section{Dr. Salem Sreeveena}

Assistant Professor in Commerce and Management Government First Grade College, Malleshwaram, Bangalore.

With rapid increase in population, the planet is pressurized with heavy consumption of goods and services, which has lead to degradation of environment of the planet. Imbalance has caused due to heavy depletion of natural resources which further paved path to problems such as Climate Change, Global Warming, Disasters like Tsunami and Earthquakes etc, Thus there are many issues and problems which are posing problems to all the countries on the earth. This has created the stung reactions from active group of environmentalists. Government intervention has become essential to fix things up. Thus pressure from public cry of active environmentalists, government policies and other stake holders are putting pressure on companies to produce products, which are in tune with the environment. This led to a new jargon in the production and marketing arena, called as "Green marketing". American Marketing Association, defines Green marketing as "marketing of products that are presumed to be environmentally safe. A holistic and responsible strategic management process that identifies, anticipates, satisfies and fulfils stakeholder needs, for a reasonable reward, that does not adversely affect human or natural environmental well-being". Green marketing incorporates a broad range of activities, including product modification, change to the production process, as well as modifying advertising. Thus "Green marketing" refers to holistic marketing concept wherein the production, marketing consumption and disposal of products and services happen in a manner which are ultimately environmental friendly. Now, both buyers and sellers have developed the concern about the future of the world and as its effects on customers buying attitude for preferring environment friendly or eco-friendly products. By considering this change in preferences of customers the production companies have changed their production process and are tending to produce more eco-friendly products. This paper analyses, the growth trends, opportunities and challenges in the way of achieving green marketing attempts.

\section{Introduction:}

According to Peattie (2001), the evolution of green marketing has three phases. First phase was termed as "Ecological" green marketing and during this period all marketing activities were concerned to help environment problems and provide remedies for environmental problems. Second phase was "Environmental" green marketing and the focus shifted on clean technology that involved designing of innovative new products, which take care of pollution and waste issues. Third phase was "Sustainable" green marketing. It came into prominence in the late 1990s and early 2000 . The products, which are manufactured through a process or adopting technology which causes no environmental hazards, are called as green products. Promotion of green technology and green products is necessary for conservation of natural resources and sustainable development. Green products are defined by following measures:

- Products those are naturally grown, recyclable, reusable and biodegradable.

- Products with natural ingredients, containing recycled contents, non-toxic chemical and content under approved chemicals.

- Products that do not harm or pollute the environment and that will not be tested on animals.

- Products that have eco-friendly packaging that are reusable, refillable containers etc.

As human wants are unlimited are resources capable of satisfying those wants are scarce, it is important for the marketers to utilize the resources effectively and efficiently without wasting it and at the same time to achieve the organization's objective. So green marketing is the need of the hour. There is growing interest among the consumers over the globe regarding protection of environment. Worldwide evidence indicates that now, people are concerned about the environment like never before and are changing their behavior and attitude towards nature. As a result of this, green marketing has emerged, which speaks for growing market for sustainable and socially responsible products and services. In common parlance a majority of people believe that green marketing refers solely to the promotion or Advertising of products with environmental characteristics. Terms like phosphate free, recyclable, refillable, ozone friendly and environmental friendly are some of the concepts, which consumers most often associate with green marketing. While these terms of green marketing claims the concept of environmental friendly marketing, in general green marketing is a much broader concept, one that can be applied to consumer goods, industrial goods and even services. Thus green marketing incorporates a broad range of activities, including product modification, changes to the production process, packaging changes, as well as modifying advertising.

Many analysts are predicting that $21^{\text {st }}$ century will be a makeor-break-it year for many green businesses, as increasing competition in the green sector drives some businesses to new heights of innovation and service, while other businesses lag behind. Trends may come and go, and of course, it is impossible for any green business to stay on top of all of them, nor is it worth while to try. However, keeping track of green business trends is a great way to ensure that business stays fresh, flexible, and creative in the face of new challenges and opportunities, the surest way to green business success in $21^{\text {st }}$ century. Utilising natural resources for the production also calls for the ethical responsibility of giving something back to nature. Implementing green marketing is not going to be an easy job. The firm has to face many problems while trading products of green marketing.

\section{Need of the study:}

Green marketing has now evolved as one of the major area of interest for marketers as it may provide competitive advantages. However it requires investment in terms of technology enhancement, process modification, communicating benefits to customers etc. Many of the companies in India have started marketing themselves as green organizations due to certain government regulations and shift in the preference of the consumers worldwide. However, not much research with respect to green marketing has been done in India and there is question about the awareness of green products among consumers. The attitude 
of Indian consumers towards green products and the relationship between the attitude and behavior is also questionable. As green marketing is different from the marketing in traditional way, marketers need to know the factors that persuade the consumer to buy the green products.

\section{Review of literature:}

Oyewole, P. (2001). Identifies a conceptual link among green marketing, environmental justice, and industrial ecology. It argues for greater awareness of environmental justice in the practice for green marketing. A research agenda is finally suggested to determine consumers' awareness of environmental justice, and their willingness to bear the costs associated with it.

Karna, J., Hansen, E. \& Juslin, H. (2003) interpret that proactive marketers are the most Genuine group in implementing environmental marketing voluntarily and seeking competitive advantage through environmental friendliness. The results also give evidence that green values, environmental marketing strategies, structures and functions are logically connected to each other as hypothesized according to the model of environmental marketing used to guide this study.

Sanjay K. Jain \& Gurmeet Kaur (2004) in their study highlights that 'environmentalism' has emerged as a worldwide phenomenon. Business firms too have risen to the occasion and have started responding to environmental challenges by practicing green marketing strategies. Green consumerism has played a catalytic role in ushering corporate environmentalism and making business firms green marketing oriented. Based on the data collected through a field survey, the paper makes an assessment of the extent of environmental awareness, attitudes and behavior prevalent among consumers in India.

Donaldson (2005) in his study realized in the Great Britain initially concluded that in general the ecological attitude of consumers changed positively. This study reported the strong faith of consumers in the known commercial brands and in the feeble behavior referring to the "green" claims, which was the main cause behind the consuming failure to interpret their Concerns beyond the environment in their behavior.

The authors Dr. Sachin Vernekar, and Preeti Wadhwa, (2011) suggest business organizations to follow strategies in order to get benefits from the environmentally friendly approach as green marketing offers business incentives and growth opportunities while it may involve start-up costs, it will save money in the long term. Green marketing is still in its infancy and a lot of reformation is to be done with a view to explore its full potential.

\section{Objectives of the study}

1. To investigate the level of awareness of Indian consumers about green products and practices.

2 . To identify the brands, consumer association with green marketing practices.

3. To investigate the preferences of Indian consumers about green products.

4. To offer suggestion for policy implication of green marketing.

\section{Research Methodology:}

Type of Research: It is an exploratory research carried out to ascertain the consumer taste and preference about green product quality, price and level of satisfaction and future plans about their purchases.

Sample size: 50 respondents were interviewed about green marketing.

Study area: The study is carried out in Bangalore city.
Primary data: Collected through structured questionnaire. Secondary data: Obtained from various sources i.e. South Asian journal, Marketing management by Philip Kotler, Electronic Green journal and Internet.

Socio-economic profile of the respondents Gender of the respondents

\begin{tabular}{|c|c|c|}
\hline Respondents & No of respondents & Percentage \\
\hline Male & 30 & $60 \%$ \\
\hline Female & 20 & $40 \%$ \\
\hline Total & 50 & $100 \%$ \\
\hline
\end{tabular}

Source: Primary Data

Age of the Respondents

\begin{tabular}{|c|c|c|}
\hline Age group of respondents & No of respondents & Percentage \\
\hline Under 16 & 5 & $10 \%$ \\
\hline $16-20$ & 10 & $20 \%$ \\
\hline $21-30$ & 15 & $30 \%$ \\
\hline $31-40$ & 12 & $24 \%$ \\
\hline Above 41 & 8 & $16 \%$ \\
\hline Total & 50 & $100 \%$ \\
\hline
\end{tabular}

Source: Primary Data

Awareness sources about green marketing

\begin{tabular}{|c|c|c|}
\hline Sources & No of respondent & Percentage \\
\hline Television & 5 & $10 \%$ \\
\hline Newspaper & 10 & $20 \%$ \\
\hline Friends/Family & 6 & $12 \%$ \\
\hline Internet & 5 & $10 \%$ \\
\hline $\begin{array}{c}\text { Television and } \\
\text { Newspaper }\end{array}$ & 8 & $16 \%$ \\
\hline Newspaper and Internet & 16 & $32 \%$ \\
\hline Total & 50 & $100 \%$ \\
\hline
\end{tabular}

Source: Primary Data

Preference for green products

\begin{tabular}{|c|c|c|}
\hline Preference & No of respondents & Percentage \\
\hline Often & 13 & $26 \%$ \\
\hline Sometime & 14 & $28 \%$ \\
\hline Rare & 16 & $32 \%$ \\
\hline Never & 7 & $14 \%$ \\
\hline Total & 50 & $100 \%$ \\
\hline
\end{tabular}

Source: Primary Data

Satisfaction with quality and price of green marketing products

\begin{tabular}{|c|c|c|}
\hline Response & No of respondent & Percentage \\
\hline Yes & 38 & $76 \%$ \\
\hline No & 12 & $24 \%$ \\
\hline Total & 50 & $100 \%$ \\
\hline
\end{tabular}

Source:Primary Data

Willingness to continue with Eco-Friendly products

\begin{tabular}{|c|c|c|}
\hline Response & No of respondents & Percentage \\
\hline Yes & 22 & $44 \%$ \\
\hline No & 28 & $56 \%$ \\
\hline Total & 50 & $100 \%$ \\
\hline
\end{tabular}

Source:Primary Data

Inference:

Marketers also have the responsibility to make the consumers understand the need for and benefits of green products as compared to non-green ones. In green marketing, consumers are willing to pay more to maintain a cleaner and greener environment. Finally, consumers, industrial buyers and suppliers need to pressurize to minimize the negative effects on the environment-friendly. Green marketing assumes even more importance and relevance in developing countries like India. While governmental regulation is designed to give 
consumers the opportunity to make better decisions or to motivate them to be more environmentally responsible, there is difficulty in establishing policies that will address all environmental issues. For example, guidelines developed to control environmental marketing address only a very narrow set of issues, i.e., the truthfulness of environmental marketing claims. If governments want to modify consumer behavior they need to establish a different set of regulations. Thus governmental attempts to protect the environment may result in a proliferation of regulations and guidelines, with no one central controlling body.

Factors influencing buying behavior of green products:

Totally 12 factors have been identified, which motivates consumers to buy green products. Rank in order preference scale has been used to find the most influencing and least influencing factors of respondents buying behavior. The details of which is narrated as follows:

\begin{tabular}{|c|c|c|c|}
\hline Factors & Rank & Factors & Rank \\
\hline Green Awareness & 7.22 & Reduced waste & 7.57 \\
\hline $\begin{array}{c}\text { Social } \\
\text { responsibility }\end{array}$ & 7.46 & Product certification & 6.32 \\
\hline Price & 7.40 & Recommended/wom & 6.90 \\
\hline $\begin{array}{c}\text { Quality of the } \\
\text { product }\end{array}$ & 3.86 & $\begin{array}{c}\text { To set example for } \\
\text { others }\end{array}$ & 8.71 \\
\hline After sales service & 5.93 & Product convenience & 7.23 \\
\hline Brand & 4.55 & Life style & 4.85 \\
\hline
\end{tabular}

Source: Primary data

\section{Test Statistics Results}

Friedman Test has been used to perform stastical investigation to arrive at inferences. The results are collated as follows.

\begin{tabular}{|c|c|}
\hline $\mathrm{N}$ & 50 \\
\hline Chi-square value & 312.029 \\
\hline Degree of freedom (n-1) & 11 \\
\hline Asymp Sig. & $.000 *$ \\
\hline
\end{tabular}

Level of significance $=5 \%$

Here the most valid preference is the factor having the least mean, as the rank 1 should have the least mean in the rank order of preferences (mean rank 3.86). Therefore, according to the mean rank preferences, selected customers who prefer shopping goods are motivated by quality of products. Further, the variation in the rank preferences of customers is tested by using Freidman test and it is found that the value of the Freidman's Chi-square is statistically significant at 5 per cent level of significance (Value of Friedman Chi-square is 312.029 with $p=0.000<0.05$ ). The next factor which has least mean is the products brand (mean 4.55). The respondents claimed that quality is a very significant factor which influences their preference for buying goods. When the customer uses a product, he is able to determine the quality of the product.

\section{Findings of the study:}

- Most of consumers are aware about eco-friendly products and services and they want to use all that but they want all these products on their budget.

- Eco-friendly products are comparatively quite expensive to normal product.

- Out of the total respondents 30 were male and 20 were female.

- $37 \%$ of the respondents were under the age group of $21-$ 30.

- Most of the respondents were working professionals.

- There are many sources for creating awareness about environmental friendly products. Television, Newspaper, Internet, personal interactions are the most important one. Out of all these, newspaper appears to be the important source of creating awareness about green marketing.

- Awareness about green marketing is picking up now a days, as people are using more and more environmental friendly products.

- Most of the respondents prefer to buy green products, despite the fact that they are little expensive.

- Surprisingly $68 \%$ of the respondents replied they want to buy green products but, cost effectiveness is very important to them. Hence they haven't prioritized.

- The Green marketing channels doesn't create the necessary awareness about the products.

- Government regulation compels the organizations in going for environmental friendly products.

- Competitive pressure also forces them to think about green products.

- Green marketing certainly helps in creating a healthy environment.

\section{Suggestions:}

Green or eco-friendly product contain good quality but they are more expensive than regular products. Therefore companies, producing eco-friendly products should try to reduce cost. Government and business concerns should have work together for creating awareness among consumers. Firms marketing goods with environmental characteristics will have a competitive advantage over firms marketing nonenvironmentally responsible alternatives. In couple of cases firms have jumped on the green bandwagon without considering the accuracy of their behavior, their claims or the effectiveness of their products. This lack of consideration of the true "greenness" of activities may result in firms making false or misleading green marketing claims. Government plays a major role in endorsing green purchasing and thus, increases the production and consumption of environmental friendly products. Governments must take serious action towards environmental sustainability through various programs and establishments. A sizable number of people believe that protecting the environment is the responsibility of the government even though they have portrayed high environmental concern.

\section{Conclusion:}

It is the right time to select and to adopt Green Marketing, not only locally but globally. It will result with drastic change in the world of business if all nations will make strict rules and guidelines. Green marketing is essential to save world from pollution. From the business point of view because a clever marketer is one who not only convinces the consumer, but also involves the consumer in marketing his product. Green marketing should not be considered as just one more approach to marketing, but has to be pursued with much greater vigor, as it has an environmental and social dimension to it. With the threat of global warming looming large, it is extremely important that green marketing becomes the norm rather than an exception or just a fad. Recycling of paper, metals, plastics, etc., in a safe and environmentally harmless manner should become much more systematized and universal. Information dissemination is the need of the hour. The user, must be told the virtues of the product. More emphasis must be given in this direction.

\section{References:}

1. Kotler, Philip. Marketing Management - The Millennium Edition Prentice Hall of India Private Limited, New Delhi

2. Brahma,M.\&Dande,R. (2008), The Economic Times, Mumbai.

3. Mathur, L.K., Mathur, I. (2000).An Analysis of the wealth effect of green marketing strategies, Journal of Business Research, 50(2), 193-200.

4. Prothero, A. \& Fitchett, J.A. (2000). Greening Capitalism: Opportunities for Green Community.Journal of Macro marketing, 20(1),pp. 46-56.

5. Sanjay K. Jain \& Gurmeet kaur (2004), Green Marketing: An Attitudinal and Behavioral Analysis of Indian Consumers, Global Business Review,Vol.5 no. 2 187-205.

6. www.google.com

7. Asia pacific journal of marketing and management issues. 